\title{
Hozzászólás az értelmiség felelősségéhez
}

\section{HOZZÁSZÓLÁS PIERRE LÉVY „AZ ÉRTELMISÉG ÚJ FELELŐSSÉGE} A KOMMUNIKÁCIÓ KORÁBAN” CÍMÜ ÍRÁSÁHOZ

\section{Szerzői információ:}

Benczúr András

A matematikai tudományok doktora. 1967-tól az MTA Számítóközpontjának (késóbbi nevén SZTAKI) valószínứségszámítási és statisztikai osztályán dolgozott, késóbb a Számítógépalkalmazási Kutató Intézet) egyik osztályát, majd Állami Népességnyilvántartó Hivatal fejlesztési foóosztályát vezette. 1983-ban az ELTE Számítóközpont tudományos fő́munkatársa és igazgatóhelyettese lett. Adatbázis-kutatásaiért társaival együtt 1988-ban Akadémiai Díjat kapott. 1990 óta egyetemi tanár. A University of North Carolina vendégprofesszoraként tanított az USA-ban is. 1996-tól az ELTE tanszékvezetője, 1997-tól 2001-ig a Természettudományi Kar dékánja volt. Az MTA Informatikai és Számítástudományi Bizottságának korábbi elnöke, jelenleg alelnöke.

E-mail: abenczur@ullman.inf.elte.hu

Így hivatkozzon erre a cikkre:

Benczúr András. „Hozzászólás az értelmiség felelősségéhez”.

Információs Társadalom VIII, 4. szám (2008): 15-17.

— https://dx.doi.org/10.22503/inftars.VIII.2008.4.3

A folyóiratban közölt müvek

a Creative Commons Nevezd meg! - Ne add el! - Így add tovább! 4.0

Nemzetközi Licenc feltételeinek megfelelően használhatók. 
Benczúr András

\section{Hozzászólás az értelmiség felelós ségéh ez}

A vitaindító cikk az informatikai tudomány és az információs technológiák nézôpontját képviselő kutató nézốpontjából erôsen kritizálható: torzítja a feladatot, túlzottan előtérbe helyezi a szerző ugyanott közölt másik cikkének fő kérdését, a „szemantikai címkézési rendszert” és „a nooszféra matematikailag felfedezhető világmindenségként való bemutatását". A cikket lehetne kritizálni oly módon is, hogy a szakmai hibákra hívjuk fel a figyelmet, de nem biztos, hogy az értelmiség új felelősségéhez ettól közelebb kerülnénk.

Nincs elég idő ahhoz, hogy az értelmiség új, összetett felelősségérôl kifejtsem nézetemet. Mindössze azt az elsớ reakciót tudom rögzíteni, amit a dolgozat olvasása kiváltott bennem.

Kiindulásként visszautalnék Kemény Jánosnak az ember és a számítógép szimbiózisára vonatkozó gondolataihoz. Nem a „hiperdokumentumok” elérése, nem a közös digitális memória és nem is a kollektív intelligencia (amit nem is értek pontosan) és az erre épülő új lehetôségek kiaknázása a központi kérdés, hanem az, hogy a „világhálóval" egyénileg vagy kisebb-nagyobb, akár az egész világot átfogó közösségekként egészséges vagy egészségtelen szimbiózisban fogunk-e élni. Azt már látni lehet, hogy a szimbiózis kialakulóban van, elkerülhetetlen. Ez a szimbiózis nem csupán szimbolikus rendszereket jelent, a digitális tárakban egybeépül a szimbolikus és nem szimbolikus tartalom.

A hetvenes évek elején Herbert Simon és Kemény János így jellemezték az információs rendszereket: „Simon tétele az, hogy egy jó információs rendszer ne a lehetố legtöbb információval lásson el bennünket, hanem a lehetö legkevesebbel, ami a munkánkhoz kell." „Információgazdag világban éliink, a probléma nem az elégtelen információból adódik, hanem éppen abból az információáradatból, amit képtelenek vagyunk feldolgozni” (Kemény János: $A z$ ember és a számitógép, 1971, 128.

Az informatika feladata, hogy csökkentse és ne fokozza az információs zúrzavart. Az információ szelektálásának problémája nem új keletú, most azonban az új lehetôségek fokozottan az elótérbe állítják.

A könyvekkel való szimbiózis feszültségeire is találunk szép megfogalmazásokat, Vörösmarty Gondolatok a könyvtárban címú költeményében vagy Kölcsey Parainesisében.

Ezek közül egy idézetcsokor szerepelt a Természet Világa informatikai különszámába 2000-ben írt cikkemben: ezeket a gondolatokat kellene értelmezni a jelenlegi informatikai fejlôdés viszonyaira.

Emlékezzünk Vörösmarty vívódására a Gondolatok a könyvtárban ma is aktuális soraiban (elég csak a webet behelyettesíteni a könyvtár helyébe): 


\author{
„Miért e lom? hogy mint juh a gyepen \\ Legeljünk rajta? s léha tudománytól \\ Zabáltan elhenyéljiik a napot? \\ Az isten napját! nemzet életét! \\ $\ldots$ \\ De hát ledöntsük, amit ezredek \\ Ész napvilága mellett dolgozának? \\ $S$ mit a tapasztalás arany \\ Bányáiból kifejtett az idô??"
}

Kölcsey a Parainesis Kölcsey Kálmánhoz oldalain számos idetartozó intelmet fogalmaz meg, amelyekból hármat idézek:

„Törekedjél ismeretekre! de ismeretekre, melyek itélet és islés által vezéreltetnek. E vezérlet hijával sok ismeret birtokába juthatsz ugyan, hanem ismereteid hasonlók lesznek a szertelen sürú vetéshez, mely gazdag növésü szálakat hoz mag nélkuil. Ítélet által rendbe szedett s keresztülgondolt ismeret ver mély gyökeret, sóriz meg a felïletességtól; i̇lés pedig adja azon kellemes szint, mi nélkül a tudomány setét és zordon: mint a cellába zárkózott remetének erkölcse. [...]

A bölcsesség legnagyobb mestere az élet; azonban gyakran felkeresd a rég elhúnytakat is, kik tanulások, vizsgálatok és tapasztalatok által gyüjtött kincseiket a maradék számára könyveikbe letették. De jusson eszedbe: a könyvek száma végtelen, a te éveid végesek; sóráidat s napjaidat sok egyéb foglalatosság kivánja magának. Mint üres beszédü társalkodót: úgy keriuld a tartalmatlan könyvet. [...] Azélet csak úgy éri el célját, ha tetteknek szentelik. Célt és véget nem tudó olvasás rest életnek következménye vagy szerzóje;

Könyvet írni: ez is egyike korunk betegségeinek. Ki kenyérért irogat, az méltóbb a szánásra, mint aki napszámért kapál. Kit hajlandóság vonz irásra, jusson eszébe: miképp hajlandóság és tehetség két különbözö dolog; s ki a hajlandóságot tehetségnek veszi: az mindég csalatkozik. Több kivántatik az irótól, mint a beszélótól."

Ehhez képest mi történik ma? Fokozódik a zúrzavar. Nemcsak „ítélet és ízlés” nélküli írásokkal tömjük tele a világhálót, hanem hasonló módon az instrumentumokkal felvett képek, mozgóképek, hang-és videofelvételek is elárasztanak mindent. Észleléseinket is minden szûrés, korlátozás nélkül beöntjük a világhálóba. Vajon ez is benne van abban a pozitívan megfogalmazott lehetôségben, hogy „az információ és automatikus kezelési módjai az egységesülés felé haladnak az egész emberiség közös virtuális memóriájában"?

A szimbolikus rendszerek „kultúráját” vajon nem fogja elnyomni vagy felváltani a konkrét, nem szimbolikus adattömeg világa? Egyszerúbb megosztani észlelési élményeinket kamerák felvételein keresztül, mint beszélni róluk. Elóbbre sorolódik külsó élményeink, észleléseink megosztása, elszegényedhet belsố világunk kifejezhetôsége. Az emberiség szimbolikus termékei összekeverednek, és kisebbségbe kerülnek a nem szimbolikus termékekkel szemben. A szimbolikus termékekhez belsố történési világainkra - gondolatainkra - van szükség.

Hogy tudunk gondolkodni, problémákat megoldani, kreatívak lenni, hogyan lesznek tetteink, ha időnk nagy részében lógunk a közös digitális memórián? Honnan lesz- 
nek rendbe szedett, keresztülgondolt ismereteinek? Hogyan választjuk ki ezeket a lomok közül?

Ezek a globális negatív hatásokra vonatkozó figyelemfelhívások. Az értelmiség feladata, hogy felhívja ezekre a veszélyekre is a figyelmet, ne csupán saját fogalmi zúrzavarán próbáljon úrrá lenni, szemantikai egységesítésekkel, a kibertér közös digitális memóriává alakításával, a gépekbe bevitt „exformációvá” vált információ korlátlan hozzáférhetôségére építve kollektív intelligenciáról álmodozni. A szemantikai címkézố rendszer segítheti a keresốmotorok szemantikailag hatékonyabb múködését, de nem oldja meg a sokkal súlyosabb kérdést: a hasznos, értékes tartalmak kiszúrését a szemétből. A szemét több, mint az érték. Szemetelünk a kibertérben. Azértelmiség feladata, hogy emelje ki a szemétbơl az értéket. Egészítse ki a világhálót az „ítélet és ízlés” szürôjével.

A beszélt és írott nyelv szerepe változóban van. A számítógépes interaktív szerkesztôi felületek a hangoknál és betúknél nagyobb elemszámú jelkészlet - legalábbis technikailag könnyú - használatával sokkal többnek a kifejezésére képesek. A vizuális információátadás sokkal gazdagabb, mint a nyelvi. A helyes és hatékony használata azonban sokkal nehezebb. Mondanivaló nélkül üres szerkesztgetéssé, másolgatássá válhat kommunikációnk. A vizuális tartalom fogalmi feldolgozása hiányossá, felületessé válik, ha nincs mögötte fogalmilag jó belsố tudásunk. Az oktatás már láthatóan küzd ennek problémáival. Mind a pozitív, mind a negatív hatások már érzékelhetók. 